\title{
Bermudagrass Drought Tolerance Associated with Dehydrin Protein Expression during Drought Stress
}

\author{
Kemin $\mathrm{Su}^{1}$ and Justin Q. Moss ${ }^{1,2}$ \\ Department of Horticulture and Landscape Architecture, Oklahoma State University, \\ 358 Agricultural Hall, Stillwater, OK 74078 \\ Guolong Zhang \\ Department of Animal Science, Oklahoma State University, Stillwater, OK 74078 \\ Dennis L. Martin \\ Department of Horticulture and Landscape Architecture, Oklahoma State University, \\ 358 Agricultural Hall, Stillwater, OK 74078 \\ Yanqi Wu \\ Department of Plant and Soil Science, Oklahoma State University, Stillwater, OK 74078
}

Additional Index words. Cynodon sp., electrolyte leakage, drought, dehydrins

\begin{abstract}
Drought stress is a major limiting factor for warm-season turfgrass growth during the summer in the U.S. transition zone. Genotypic variation in drought resistance exists among bermudagrasses (Cynodon sp.), but the mechanisms of drought resistance are poorly understood. Our objectives were to investigate physiological changes in three bermudagrass cultivars under a well-watered condition and drought stress. to determine expression differences in soluble protein and dehydrin of the three cultivars under well-watered and drought stress conditions, and to identify the association between dehydrin proteins and drought tolerance. Grasses included a high drought-resistant cultivar, Celebration, a low drought-resistant cultivar, Premier, and a newly released cultivar, Latitude 36 . In both well-watered and drought treatments, 'Latitude 36' had the highest visual quality and lower or medium electrolyte leakage among three cultivars. In the drought treatment, 16- and 23-kDa dehydrin proteins were observed in 'Latitude 36' but not in 'Celebration' or 'Premier'. Our results indicate that the 16- and 23-kDa dehydrin expressions could be associated with drought tolerance and contribute to drought tolerance in bermudagrass.
\end{abstract}

Drought is a major limiting factor for sustainable turfgrass management in the United States. Climate prediction models indicate that the world may experience increased global temperatures, decreased precipitation, and an increase in the occurrence and persistence of drought periods over the next century. A growing challenge facing the turfgrass industry is limited availability of water for irrigation (Snow, 2001). Thus, understanding the mechanisms of drought resistance is increasingly important for turfgrass breeders and managers.

Dehydrins are the late embryogenesis abundant (LEA) D 11 family of hydrophilic proteins with a wide range of molecular masses from 9 to $200 \mathrm{kDa}$ (Close, 1996). They accumulate in plants in response to environmental influence with a dehydration component such as drought, salinity, and low temperature (Beck et al., 2007; Close, 1997). These proteins have been postulated to stabilize macromolecules or cellular structure and help to maintain the integrity of cell membranes against dehydration (Beck et al., 2007; Bray, 1997; Campbell and Close, 1997; Close, 1997). Most work with dehydrins in turfgrass has been completed in cold acclimation and freezing tolerance (Gatschet et al., 1994; Patton et al., 2007; Zhang et al., 2008,

Received for publication 6 May 2013. Accepted for publication 6 June 2013. We thank the Oklahoma Center for the Advancement of Science and Technology (Project \# PSA09-04) and the Oklahoma Agricultural Experiment Station (Project \# OKL02723) for financial support. We also thank Dr. Guosheng Li, Ms. Xiaowei Pan, and Ms. Yang Tian for their technical help.

${ }^{1}$ Co-first authors.

${ }^{2}$ Corresponding author. E-mail: justin.moss@okstate.edu.
2011). There are also studies reporting that dehydrins are present in turfgrass when drought-stressed (Hu et al., 2010; Jiang and Huang, 2002; Pan et al., 2013; Volaire, 2002). Very few data exist in turfgrass that support the popular hypothesis that dehydrin accumulation is positively correlated with dehydration tolerance. Hu et al. (2010) reported that accumulation of 31- and 40-kDa dehydrins may contribute to drought tolerance in bermudagrass through investigating four hybrid bermudagrasses (Cynodon dactylon $\times$ Cynodon transvaalensis) and four common bermudagrasses $(C$. dactylon).

Bermudagrass, the most important warm-season turfgrass grown in the southern portion of the United States, is regarded as a drought-resistant species (McCarty and Miller, 2002) with genotypic variation in drought resistance. Its drought resistance mechanisms include drought avoidance and drought tolerance. Some bermudagrasses have growth features such as deeper root systems, thicker cuticles, and smaller stomatal openings, which can improve their drought avoidance (Carrow, 1995, 1996; Qian et al., 1997). Others can sustain biochemical and physiological processes during internal water deficits (Hu et al., 2010; Huang et al., 1997). Different drought resistance mechanisms among bermudagrass cultivars may exhibit different patterns of dehydrin expression in response to drought stress. Three cultivars of bermudagrass selected for this study were two common bermudagrass cultivars, Celebration and Premier, and a clonally propagated hybrid cultivar developed by Oklahoma State University, Latitude 36 . Several researchers have reported that 'Celebration' is a top-performing drought-resistant cultivar with a deep root system, whereas 'Premier' has high visual quality but 
is a drought-sensitive cultivar (Baldwin et al., 2006; Poudel, 2010; Steinke et al., 2009). 'Latitude 36', tested as OKC1119, was an excellent performer among all cultivars in the 2007 to 2011 National Turfgrass Evaluation Program (NTEP) bermudagrass test and had high turf quality rating (NTEP, 2013). However, there are few reports on the drought resistance mechanisms associated with dehydrin protein expression during drought stress. Investigations concerning the physiological bases of cultivar differences in drought resistance would provide valuable selection information for turfgrass breeders and managers. The objectives of this study were to investigate physiological changes in three bermudagrass cultivars under well-watered conditions and drought stress, to determine expression differences in soluble protein and dehydrin of three cultivars under well-watered and drought stress conditions, and to identify the association between dehydrin proteins and drought tolerance.

\section{Materials and Methods}

Plant preparation, maintenance, treatments, experiMENTAL DESIGN, AND STATISTICAL ANALYSIS. Thirty sod plugs of 'Celebration', 'Premier', and 'Latitude 36' were collected on 19 Mar. 2010 from established swards at the Oklahoma State University Turfgrass Research Center in Stillwater (lat. $36^{\circ} 63^{\prime} 56^{\prime \prime} \mathrm{N}$, long. $97^{\circ} 3^{\prime} 29^{\prime \prime} \mathrm{W}$ ) and each cultivar was planted in 10 lysimeters $(10 \mathrm{~cm}$ diameter $\times 45 \mathrm{~cm}$ deep $)$. Lysimeters were filled with a mixture of sand and silt loam topsoil $(1: 1 \mathrm{v}: \mathrm{v})$ and were maintained in a greenhouse for 3 months. The particles of sand and topsoil were less than $1 \mathrm{~mm}$ in diameter. Average day/ night air temperature was $30 / 20^{\circ} \mathrm{C}$. The supplemental light with incandescent lamps was included for $14 \mathrm{~h} \cdot \mathrm{d}^{-1}$ and average photosynthetically active radiation $(P A R)$ was $1000 \mu \mathrm{mol} \cdot \mathrm{m}^{-2} \cdot \mathrm{s}^{-1}$ in a quantum light meter (3415F; Spectrum Technologies, Plainfield, IL) during the daylight period. Grasses were clipped weekly at $5.0 \mathrm{~cm}$ and watered twice with fertilizer water at $0.25 \mathrm{~g} \cdot \mathrm{L}^{-1}$ of 20N-8.7P-16.6K water-soluble fertilizer (Jack's Professional 20-20-20; J.R. Peters, Allentown, PA).

After 3 months in the greenhouse, lysimeters were transferred to a walk-in growth chamber and acclimated for 3 weeks at optimal growth temperatures $\left(30 / 25^{\circ} \mathrm{C}, 14-\mathrm{h}\right.$ light/10-h darkness) with $P A R$ at $600 \mu \mathrm{mol} \cdot \mathrm{m}^{-2} \cdot \mathrm{s}^{-1}$ during the daylight period. Turfgrasses were mowed once per week at $5.0 \mathrm{~cm}$ and irrigated every $3 \mathrm{~d}$. To maintain well-watered conditions, 100\% of water lost through evapotranspiration (ET) during the previous $3 \mathrm{~d}$ was replaced; $100 \%$ ET was determined gravimetrically with the lysimeters (Bremer, 2003). Using this method, lysimeters were irrigated, allowed to drain until free drainage ceased, sealed, and weighed. Lysimeters were weighed again after $3 \mathrm{~d}$ and the water loss was attributed to ET. Turfgrasses were fertilized every $6 \mathrm{~d}$ with a solution supplying $16 \mathrm{~kg} \cdot \mathrm{ha}^{-1}$ nitrogen $(20 \mathrm{~N}-8.7 \mathrm{P}-16.6 \mathrm{~K})$.

On 11 July 2010, 'Celebration', 'Premier', and 'Latitude 36' were exposed to well-watered and drought treatments in the walk-in growth chamber. The lysimeters under the well-watered condition continued to be irrigated by $100 \%$ ET replacement every $3 \mathrm{~d}$ and drought treatment was conducted by completely withholding irrigation.

A randomized complete block design with five replications (i.e., five blocks) was used. Totally there were 30 lysimeters with three cultivars, two treatments, and five replications. Thirty lysimeters were used to collect for volumetric soil water content $\left(\theta_{v}\right)$, visual quality, and electrolyte leakage. These data were analyzed using the MIXED procedure of SAS (Version 9.1; SAS Institute, Cary, NC) and differences between means were separated by the SAS PDIFF option $(P=0.05)$. Eighteen lysimeters (three replications) were used to extract protein.

MEASUREMENTS OF VOLUMETRIC SOIL WATER CONTENT, VISUAL QUALITY, AND LEAF ELECTROLYTE LEAKAGE. Volumetric soil water content at 0 - to $20-\mathrm{cm}$ profile from each lysimeter was measured on 12 July 2010 [0 d of treatment (0 DOT)] and 20 July 2010 (8 DOT) using time domain reflectometry (HydroSense system; Campbell Scientific, Logan, UT).

Turf visual quality was rated on a scale of 1 to $9(1=$ poorest quality, $6=$ minimally acceptable, and $9=$ highest quality) according to color, texture, density, and uniformity (Emmons, 2000). Quality ratings were recorded on 0 and 8 DOT by the same individual.

The drought damage severity of turfgrass cell membrane was estimated by measuring leaf electrolyte leakage. Fifteen young fully expanded living leaves approximately similar age were collected from each lysimeter on 0 and 8 DOT. These young fully expanded leaves from each lysimeter were rinsed three times with distilled deionized water and placed in a test tube filled with $20 \mathrm{~mL}$ distilled deionized water. Test tubes were shaken on a shaker table at $120 \mathrm{rpm}$ for $24 \mathrm{~h}$ to dissolve the electrolytes leaking from cells resulting from the drought stress. The solution conductivity (C1) was measured with a portable conductivity meter (Accumet AP85; Fisher Scientific, Pittsburgh, PA). Then the leaf tissues were killed in an autoclave at $140{ }^{\circ} \mathrm{C}$ for $20 \mathrm{~min}$ to destroy the cell membranes, shaken for $24 \mathrm{~h}$ at room temperature to extract all the electrolytes from the cells, and the conductivity (C2) was measured again. The percentage electrolyte leakage was calculated as $\mathrm{C} 1 / \mathrm{C} 2 \times 100$ and its lower percentage indicates greater resistance to drought stress.

Protein extraction. Total soluble protein was extracted according to the procedure of Damerval et al. (1986) with minor modifications. Briefly, fully expanded leaves $(0.15 \mathrm{~g}$ fresh weight) were collected from each lysimeter on 0 and 8 DOT and grounded in a mortar and pestle with liquid nitrogen to a fine

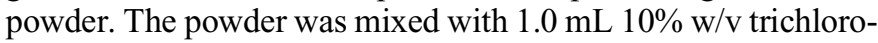
acetic acid and $0.07 \% \mathrm{v} / \mathrm{v} 2$-mercaptoethanol in cold $\left(-20{ }^{\circ} \mathrm{C}\right)$ acetone in $1.5-\mathrm{mL}$ mirocentrifuge tube. The mixture was incubated overnight at $-20{ }^{\circ} \mathrm{C}$ and vortexed four times during the incubating process. Samples were then centrifuged at $16,000 g_{\mathrm{n}}$ at $4{ }^{\circ} \mathrm{C}$ for $15 \mathrm{~min}$ and the supernatant was removed by decanting. Acetone containing $0.07 \% \mathrm{v} / \mathrm{v} 2$-mercaptoethanol ( $1 \mathrm{~mL}$ at $-20{ }^{\circ} \mathrm{C}$ ) was used to wash the pellet and remove pigments and lipids until the pellet was colorless. The pellet was dried in a Speed Vac (Thermo Electron, Waltham, MA) for $15 \mathrm{~min}$ and re-suspended in $1-\mathrm{mL}$ rehydration buffer $(8 \mathrm{M}$ urea, $2 \%$ 3-[(3-Cholamidopropyl)dimethylammonio]-1-propanesulfonate hydrate, and $50 \mathrm{~mm}$ dithiothreitol). Proteins were extracted in a water-bath sonicator (FS60; Fisher Scientific) for $30 \mathrm{~min}$ and centrifuged at $16,000 g_{\mathrm{n}}$ at $4{ }^{\circ} \mathrm{C}$ for $25 \mathrm{~min}$. The supernatant containing predominantly soluble protein was transferred to a new microcentrifuge. Next, $25-\mu \mathrm{L}$ aliquots of supernatant were removed for protein quantification. Buffer-soluble protein was estimated using the Bradford procedure (Bradford, 1976). Buffersoluble protein concentrations were determined using bovine serum albumin as a standard and absorbance was read at 595 $\mathrm{nm}$ in a spectrophotometer (Novaspec Plus; Amersham BioSciences, Piscataway, NJ). The remaining supernatant was retained for sodium dodecyl sulfate-polyacrylamide gel electrophoresis (SDS-PAGE) and immunoblotting. 
SDS-PAGE AND Immunoblotting. An aliquot of $50 \mu \mathrm{L}$ supernatant mixed with $50 \mu \mathrm{L}$ Laemmli sample buffer $(0.0625$ $\mathrm{mol} \cdot \mathrm{L}^{-1}$ Tris-HCI, $\mathrm{pH} 6.8,20 \%$ glycerol, $2 \%$ SDS, $0.01 \%$ bromophenol blue, $5 \% \beta$-mercaptoethanol) was used for SDSPAGE analysis (Laemmli, 1970) after heating 3 to $5 \mathrm{~min}$ at $100{ }^{\circ} \mathrm{C}$ in a sealed screw-cap microcentrifuge tube. Lanes were loaded with $20 \mu \mathrm{g}$ sample protein, and proteins were separated in $1.0-\mathrm{mm}$-thick gels containing $5 \%$ stacking gel and $12 \%$ running gel with the Mini-Protean Tetra Cell (Bio-Rad Laboratories, Hercules, CA). The gel was stained for $1 \mathrm{~h}$ with Bio-Safe Coomassie G-250 stain (Bio-Rad Laboratories).

For immunoblotting, SDS unstained gel containing $20 \mu \mathrm{g}$ separated proteins was transferred onto an Immun-Blot polyvinyl difluoride membrane $(0.2 \mu \mathrm{m}$; Bio-Rad Laboratories $)$ with an electrophoresis transfer unit Mini-Protean Tetra Cell (Bio-Rad Laboratories) in transfer buffer (25 mм Tris base, $192 \mathrm{~mm}$ glycine, $10 \% \mathrm{v} / \mathrm{v}$ methanol, $\mathrm{pH} 8.3$ ) at constant volts of 100 for $1 \mathrm{~h}$. The gel membrane was blocked with blocking buffer [5\% dry skim milk with $0.05 \%$ Tween 20 (Bio-Rad Laboratories) in tert-butyldimethylsilyl (TBS) $(20 \mathrm{~mm}$ tris $\mathrm{HCl}$, $150 \mathrm{~mm} \mathrm{NaCl}, \mathrm{pH} 7.5$ )] at $4{ }^{\circ} \mathrm{C}$ overnight. Then the membrane was probed with 1:250 dilution of rabbit antidehydrin polyclonal antibody (PLA-100; Enzo Life Sciences International, Plymouth Meeting, PA) for $1 \mathrm{~h}$. After being washed three times by TTBS $(0.05 \%$ Tween 20 in TBS), goat antirabbit AP secondary antibody (Bio-Rad Laboratories) was diluted in TTBS (dilution 1:3000) to incubate the membranes for $1 \mathrm{~h}$. After three washes in TTBS and one wash in TBS, a representative blotting image was detected by gently shaking the membrane immersed in color development solution [mixture of $0.2 \mathrm{~mL}$ AP color reagent A, $0.2 \mathrm{~mL}$ color reagent $\mathrm{B}$, and $19.6 \mathrm{~mL} 1 \times$ color development buffer (Bio-Rad Laboratories)] at room temperature on a shaker table at $30 \mathrm{rpm}$ (Midwest Scientific, St. Louis, MO). The SDS-PAGE and immunoblotting were conducted for three replications and the representative data are presented here.

\section{Results and Discussion}

RESPONSES OF VOLUMETRIC SOIL WATER CONTENT, VISUAL QUALITY, AND LEAF ELECTROLYTE LEAKAGE TO DROUGHT STRESS. Volumetric soil water content at 0 - to $20-\mathrm{cm}$ profile was higher in 'Premier' than in 'Latitude 36' under well-watered treatment on 0 DOT, although absolute differences in $\theta_{\mathrm{v}}$ at 0 - to 20 -cm profile among the three cultivars were markedly small (i.e., $\theta_{\mathrm{v}}$ at 0 to $20 \mathrm{~cm}$ ranged from $30.0 \%$ to $31.8 \%$ ) (Fig. 1A). Under the drought treatment and well-watered treatment on 8 DOT, there were no differences in $\theta_{\mathrm{v}}$ at 0 - to $20-\mathrm{cm}$ profile among three cultivars (i.e., three bermudagrass cultivars received the same level of drought stress). On 8 DOT, the drought treatment reduced $\theta_{\mathrm{v}}$ at $0-$ to $20-\mathrm{cm}$ profile to $7.6 \%$ to $9.0 \%$ (Fig. $1 \mathrm{~A}-\mathrm{B}$ ).

In well-watered conditions, visual quality was highest in 'Latitude 36' and lower, but similar, between 'Celebration' and 'Premier' (Fig. 2A). Lower visual quality in 'Celebration' was primarily the result of its coarse leaf texture. Higher turf quality in 'Latitude 36' than in 'Premier' was also reported in the 2007 to 2011 NTEP bermudagrass test (NTEP, 2013). Drought stress reduced visual quality among three cultivars. On 8 DOT, the drought stress reduced visual quality $10.0 \%$ in 'Celebration', $15.6 \%$ in 'Latitude 36', and 19.0\% in 'Premier'. However, visual quality was higher in 'Latitude 36' than in 'Celebration' and 'Premier' mainly because of its fine leaf texture (Fig. 2B).

On 0 DOT in well-watered and drought conditions, living leaf electrolyte leakage (EL) was higher in 'Premier' than in 'Celebration', although absolute differences in EL among the three cultivars were markedly small (i.e., EL ranged from $2.0 \%$ to $3.3 \%$ at 0 DOT in well-watered and from $2.4 \%$ to $3.5 \%$ at 0 DOT in drought conditions) and there was no difference between 'Celebration' and 'Latitude 36' (Fig. 3A-B). After exposure to drought, the EL in 'Celebration', 'Latitude 36', and 'Premier' were 3.5\%, 4.7\%, and 6.2\%, respectively (Fig. 3B). Electrolyte leakage was lowest in 'Celebration' and highest in 'Premier' indicating less damage to cellular membranes in 'Celebration' and more damage to cellular membranes in 'Premier'. These data showed that 'Celebration' has greater drought resistance likely because 'Celebration' may use its deeper root system to absorb deeper soil water in the lysimeters, thus avoiding drought stress. Steinke et al. (2009) reported that the mean canopy temperature was lower in 'Celebration' than in 'Premier' on several measurement dates during the 60-d drought in a 2-year field study. Lower canopy temperatures in
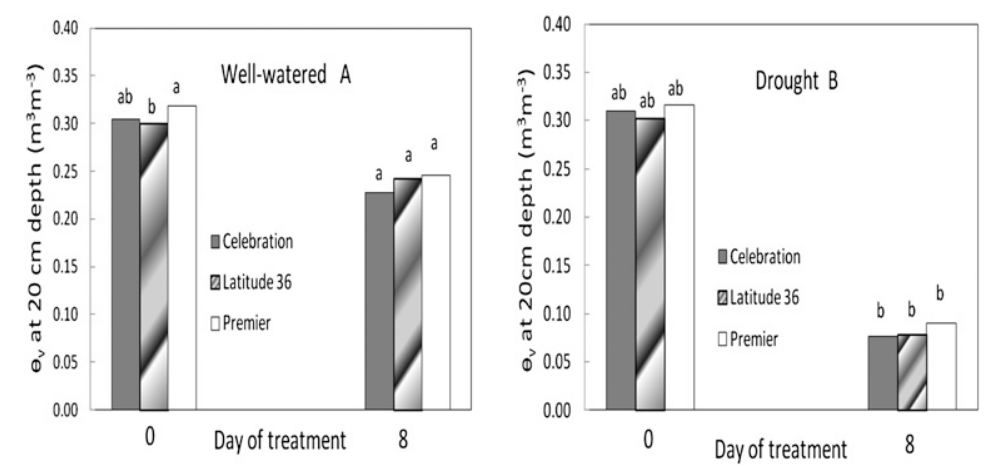

Fig. 1. Soil water content at 0 - to 20 -cm depth of bermudagrass 'Celebration', 'Latitude 36', and 'Premier' under well-watered (A) and drought (B) conditions. Means with the same letters on a given day after treatment initiation (day of treatment) were not significantly different $(P=0.05)$.
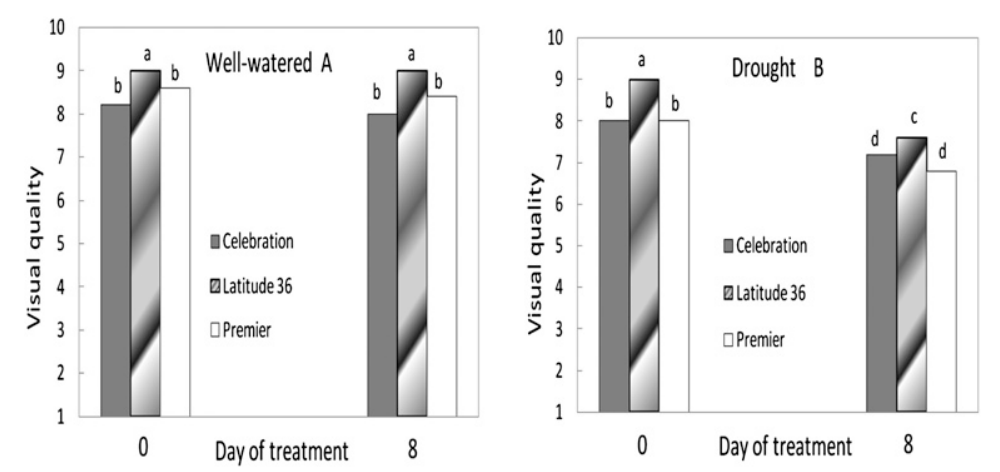

Fig. 2. Visual quality rated on a scale of 1 to $9(1=$ poorest and $9=$ highest $)$ of bermudagrass 'Celebration', 'Latitude 36', and 'Premier' under well-watered (A) and drought conditions (B). Means with the same letters on a given day after treatment initiation (day of treatment) were not significantly different $(P=0.05)$. 
'Celebration' may enhance heat dissipation through greater evapotranspiration and allowing it to maintain leaf turgor longer in the drought situation.

Protein Changes. The SDS-PAGE analysis of buffersoluble protein from leaves indicated that all polypeptides maintained stable bands in response to drought stress. There were similar SDS-PAGE profiles of buffer-soluble protein from leaves of 'Celebration', 'Latitude 36', and 'Premier' under wellwatered and drought conditions (Fig. 4).

Immunoblots indicated that dehydrin polypeptides of $\approx 16$ and $23 \mathrm{kDa}$ were detected in 'Latitude 36' under the drought treatment at 8 DOT but no dehydrin proteins were observed in 'Celebration' and 'Premier' under the drought condition and no dehydrin polypeptides were detected in three cultivars under the well-watered condition (Fig. 5). Drought-induced dehydrin polypeptides have been observed in many turfgrass studies $(\mathrm{Hu}$ et al., 2010; Jiang and Huang, 2002; Volaire, 2002). Jiang and Huang have found that $23-$ and $27-\mathrm{kDa}$ dehydrin polypeptides
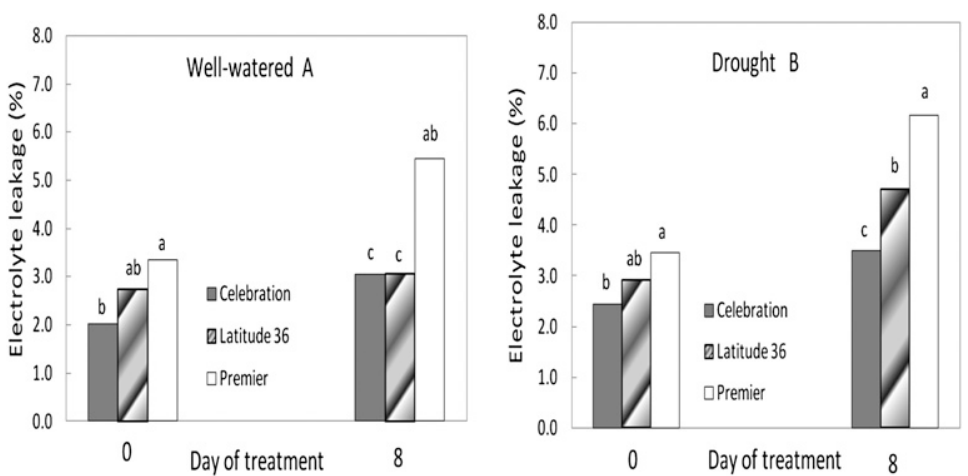

Fig. 3. Living leaf electrolyte leakage of bermudagrass 'Celebration', 'Latitude 36', and 'Premier' under well-watered (A) and drought conditions (B). Means with the same letters on a given day after treatment initiation (day of treatment) were not significantly different $(P=0.05)$.

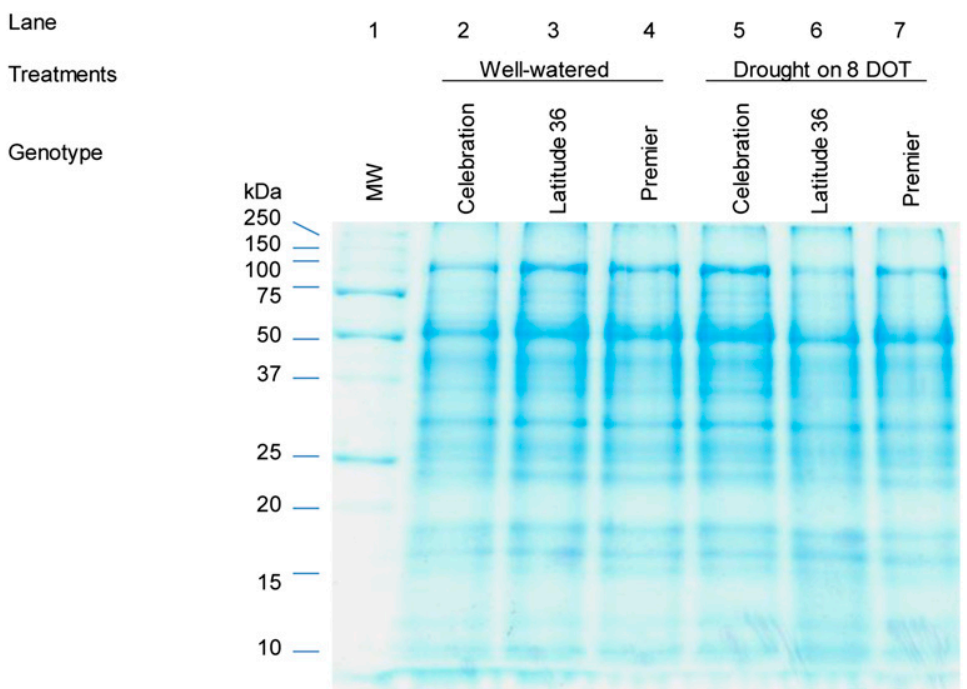

Fig. 4. Dodecyl sulfate polyacrylamide gel electrophoresis (SDS-PAGE) profiles of buffer-soluble protein from leaves of bermudagrass 'Celebration', 'Latitude 36', and 'Premier' under well-watered and drought conditions. Lane 1, molecular marker; lane 2, 'Celebration' under well-watered condition; lane 3, 'Latitude 36' under well-watered condition; lane 4, 'Premier' under well-watered condition; lane 5, 'Celebration' under $8 \mathrm{~d}$ drought stress [drought on $8 \mathrm{~d}$ of treatment (DOT)]; lane 6, 'Latitude 36' under $8 \mathrm{~d}$ drought stress; lane 7, 'Premier' under $8 \mathrm{~d}$ drought stress. Equal amounts of buffer-soluble protein $(20 \mu \mathrm{g})$ were loaded into each lane. were observed at $10 \mathrm{~d}$ in drought stress and were more pronounced in the drought-stressed tall fescue (Festuca arundinacea) without abscisic acid. Our results in 'Latitude 36' also polypeptides were also not present in the drought resis cultivar Celebration under the drought treatment. It is mainly because of its different drought resistance mechanisms. Poudel less drought damage to cellular membranes in 'Celebration'. Under the condition at 8 DOT, the three bermudagrass cultivars received the same level of drought stress in the $0-$ to $20-\mathrm{cm}$ profile, and our lysimeters were $45 \mathrm{~cm}$ deep. 'Celebration' may use its deep root system to absorb deeper soil water in the lysimeters and avoided drought stress. Our results also supported the popular hypothesis that dehydrin accumulation is positively correlated with drought tolerance (Beck et al., 2007; Close, 1997; Close et al., 1993; Hu et al., 2010; Labhilili et al., 1995; Lopez et al., 2003).

Our results suggest that dehydrin polypeptides of 16 and $23 \mathrm{kDa}$ play a role in drought tolerance of bermudagrass. The function of $16 \mathrm{kDa}$ for drought tolerance in our study is consistent with other findings in wheat [Triticum durum (Labhilili et al., 1995)] and olive [Oleae europaea (Tripepi et al., 2011)]. Lopez et al. (2003) found that expression of a 24-kDa dehydrin was observed in some drought-tolerant wheat (Triticum aestivum) cultivars after $4 \mathrm{~d}$ of drought stress and positively associated with drought tolerance in wheat. As far as the function of $23 \mathrm{kDa}$ was concerned, several researchers reported that the 23-kDa dehydrin polypeptides were associated with chilling or freezing tolerance (Kang et al., 2005; Patton et al., 2007). Gatschet et al. (1994) have reported that accumulation of low-molecular-weight (20 to $26 \mathrm{kDa}$ ) cold-regulated proteins similar to dehydrins was positively correlated to freeze tolerance in bermudagrass. Cold and drought affect similarly the water relations of plant at the cellular or whole plant levels (Beck et al., 2007). The molecular weight of dehydrin proteins varies from 9 to $200 \mathrm{kDa}$ (Close, 1996). The wide range of molecular weights in dehydrin proteins is caused by the repeat number of $\mathrm{K}$ segments, which is a 15 amino acid consensus sequence (EKKGIMDKIKEKPLG). The $\mathrm{K}$ segment resembles lipid-binding class $\mathrm{A}_{2}$ amphipathic $\alpha$-helical proteins and stabilizes the cell membrane to tolerate drought 


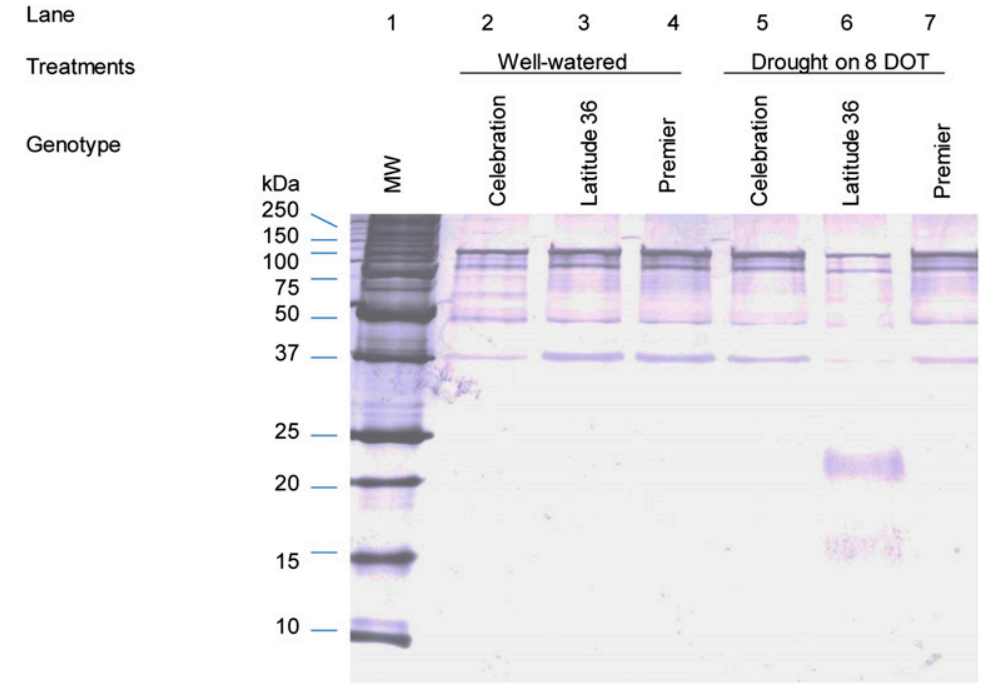

Fig. 5. Immunoblots of buffer-soluble protein from leaves of bermudgrass 'Celebration', 'Latitude 36', and 'Premier' under well-watered and drought conditions and probed with 1:250 dilution of rabbit antidehydrin polyclonal antibody. Lane 1, molecular marker; lane 2, 'Celebration' under well-watered condition; lane 3, 'Latitude 36' under well-watered condition; lane 4, 'Premier' under well-watered condition; lane 5, 'Celebration' under $8 \mathrm{~d}$ drought stress [drought on $8 \mathrm{~d}$ of treatment (DOT)]; lane 6, 'Latitude 36' under 8 d drought stress; lane 7, 'Premier' under 8 d drought stress. All lanes were loaded with $20 \mu \mathrm{g}$ buffer-soluble protein.

stress (Close, 1997; Davidson et al., 1998; Koag, et al., 2003). The contribution of dehydrins to drought tolerance is achieved by considering dehydrins as membrane stabilizers and involving alleviation of cell damage during drought stress although the precise mechanisms is still to be explored (Bartels and Sunkar, 2005; Koag et al., 2003). Moreover, Goyal et al. (2005) provided the first evidence of antiaggregation activity of $L E A$ proteins resulting from water stress. Larsson et al. (2006) reported that drought stress changed membrane phospholipid composition by enhancing phosphatidylserine decarboxylase activity in root cells of oat (Avena sativa). Our previous study of membrane lipid composition and drought tolerance of the same three bermudagrass cultivars indicated that lower monogalactosyldiacylglycerol and higher phospholipid contents contributed to drought tolerance in bermudagrass ( $\mathrm{Su}$ et al., 2013). Therefore, more research is needed to identify the association between dehydrin proteins and drought tolerance to decide whether these dehydrin proteins could be used as practical protein markers for drought tolerance.

\section{Conclusions}

Our data indicate that 'Latitude 36' had the highest visual quality and lower or medium EL among three cultivars in both well-watered and drought treatments. In the drought treatment, 16- and 23-kDa dehydrin proteins were observed in 'Latitude 36'. Our results indicate that the 16- and 23-kDa dehydrin expressions could be associated with drought tolerance and contribute to drought tolerance in bermudagrass.

\section{Literature Cited}

Baldwin, C.M., H. Liu, L.B. McCarry, W.L. Bauerle, and J.E. Toler. 2006. Response of six bermudagrass cultivars to different irrigation intervals. HortTechnology 16:466-470.

Bartels, D. and R. Sunkar. 2005. Drought and salt tolerance in plants. Crit. Rev. Plant Sci. 24:23-58.
Beck, E.H., S. Fettig, C. Knake, K. Hartig, and T. Bhattarai. 2007. Specific and unspecific responses of plants to cold and drought stress. J. Biosci. 32:501-510.

Bradford, M.M. 1976. A rapid and sensitive method for the quantification of microgram quantities of protein utilizing the principle of a protein-dye binding. Anal. Biochem. 72:248-254.

Bray, E.A. 1997. Plant responses to water deficit. Trends Plant Sci. 2:48-54.

Bremer, D.J. 2003. Evaluation of microlysimeters used in turfgrass evapotranspiration studies using the dual-probe heat-pulse technique. Agron. J. 95:1625-1632.

Campbell, S.A. and T. Close. 1997. Dehydrins: Genes, proteins, and associations with phenotypic traits. New Phytol. 137:61-74.

Carrow, R.N. 1995. Drought resistance aspects of turfgrasses in the southeast: Evapotranspiration and crop coefficients. Crop Sci. 35:1685-1690.

Carrow, R.N. 1996. Drought resistance aspects of turfgrasses in the Southeast: Root-shoot responses. Crop Sci. 36:687-694.

Close, T.J. 1996. Dehydrins: Emergence of a biochemical role of a family of plant dehydration proteins. Physiol. Plant. 97:795-803.

Close, T.J. 1997. Dehydrins: A commonalty in the response of plants to dehydration and low temperature. Physiol. Plant. 100:291-296.

Close, T.J., R.D. Fenton, and F. Moonan. 1993. A view of plant dehydrins using antibodies specific to the carboxy terminal peptide. Plant Mol. Biol. 23:279-286.

Damerval, C., D.D. Vienne, M. Zivy, and H. Thiellement. 1986. Technical improvements in two-dimensional electrophoresis increase the level of genetic variation detected in wheat-seedling proteins. Electrophoresis 7:52-54.

Davidson, W.S., A. Jonas, D.F. Clayton, and J.M. George. 1998. Stabilization of alpha-synuclein secondary structure upon binding to synthetic membranes. J. Biol. Chem. 273:9443-9449.

Emmons, R.D. 2000. Turfgrass science and management. 3rd Ed. Delmar, Albany, NY.

Gatschet, M.J., C.M. Taliaferro, J.A. Anderson, D.R. Porter, and M.P. Anderson. 1994. Cold acclimation and alterations in protein synthesis in bermudagrass crowns. J. Amer. Soc. Hort. Sci. 119:477-480.

Goyal, K., L.J. Walton, and A. Tunnacliffe. 2005. LEA proteins prevent protein aggregation due to water stress. Biochem. J. 388:151-157.

Hu, L., Z. Wang, H. Du, and B. Huang. 2010. Differential accumulation of dehydrins in response to water stress for hybrid and common bermudagrass genotypes differing in drought tolerance. J. Plant Physiol. 167:103-109.

Huang, B., R.R. Duncan, and R.N. Carrow. 1997. Drought-resistance mechanism of seven warm-season turfgrasses under surface soil drying: I. Shoot response. Crop Sci. 37:1858-1863.

Jiang, Y. and B. Huang. 2002. Protein alterations in tall fescue in response to drought stress and abscisic acid. Crop Sci. 42:202-207.

Kang, H., K. Park, and M.E. Saltveit. 2005. Chilling tolerance of cucumber (Cucumis sativus) seedling radicles is affected by radicle length, seedling vigor, and induced osmotic-and heat-shock proteins. Physiol. Plant. 124:485-492.

Koag, M., R.D. Fenton, S. Wilkens, and T.J. Close. 2003. The binding of maize DHN1 to lipid vesicles. Gain of structure and lipid specificity. Plant Physiol. 131:309-316.

Labhilili, M., P. Joudrier, and M.F. Gautier. 1995. Characterization of cDNAs encoding Triticum durum dehydrins and their expression patterns in cultivars that differ in drought tolerance. Plant Sci. 112:219-230.

Laemmli, U.K. 1970. Cleavage of structural proteins during the assembly of the head of bacteriophage T4. Nature 227:680-685. 
Larsson, K.E., B. Nyström, and C. Liljenberg. 2006. A phosphatidylserine decarboxylase activity in root cells of oat (Avena sativa) is involved in altering membrane phospholipid composition during drought stress acclimation. Plant Physiol. Biochem. 44:211-219.

Lopez, C.G., G.M. Banowetz, C.J. Peterson, and W.E. Kronstad. 2003. Dehydrin expression and drought tolerance in seven wheat cultivars. Crop Sci. 43:577-582.

McCarty, L.B. and G. Miller. 2002. Managing bermudagrass turf: Selection, construction, cultural practices and pest management strategies. Sleeping Bear Press, Chelsea, MI.

National Turfgrass Evaluation Program. 2013. Bermudagrass data. 4 June 2013. <http://www.ntep.org/bg.htm>.

Pan, X., J.Q. Moss, Y. Wu, N.O. Maness, and K. Su. 2013. Tall fescue performance and protein alteration during drought stress. Intl. Turfgrass Soc. Res. J. 12:465-473.

Patton, A.J., S.M. Cunningham, J.J. Volenec, and Z.J. Reicher. 2007. Differences in freeze tolerance of zoysiagrass: I. Role of proteins. Crop Sci. 47:2162-2169.

Poudel, B.P. 2010. Testing of clonal bermudegrass cultivars and experimental genotypes for differences in drought performance. MS thesis, Oklahoma State Univ., Stillwater, OK.

Qian, Y., J.D. Fry, and W.S. Upham. 1997. Rooting and drought avoidance of warm-season turfgrasses and tall fescue in Kansas. Crop Sci. 37:905-910.
Snow, J.T. 2001. Water conservation on golf courses. 4 June 2013. $<$ http://www.usga.org/course_care/articles/environment/water/ Water-Conservation-on-Golf-Courses $>$.

Steinke, K., D.R. Chalmers, J.C. Thomas, and R.H. White. 2009. Summer drought effects on warm-season turfgrass canopy temperatures. Appl. Turfgrass Sci. doi: 10.1094/ATS-2009-0303-01-RS. 4 June 2013. <http://www.plantmanagementnetwork.org/sub/ats/ research/2009/Canopy/Canopy.pdf>.

Su, K., J.Q. Moss, G. Zhang, Y. Wu, and D.L. Martin. 2013. Membrane lipid composition and drought tolerance in bermudagrass. Intl. Turf. Soc. Res. J. 12:445-452.

Tripepi, M., M. Pöhlschroder, and M.B. Bitonti. 2011. Diversity of dehydrins in Oleae europaea plants exposed to stress. Open Plant Sci. J. 5:9-13.

Volaire, F. 2002. Drought survival, summer dormancy and dehydrin accumulation in contrasting cultivars of Dacylis glomerata. Physiol. Plant. 116:42-51.

Zhang, X., K. Wang, and E.H. Ervin. 2008. Bermudagrass freezing tolerance associated with abscisic acid metabolism and dehydrin expression during cold acclimation. J. Amer. Soc. Hort. Sci. 133:542-550.

Zhang, X., K. Wang, E.H. Ervin, C. Waltz, and T. Murphy. 2011. Metabolic changes during cold acclimation and deacclimation in five bermudagrass varieties. I. Proline, total amino acid, protein, and dehydrin expression. Crop Sci. 51:838-846. 